\title{
Rapport in EFL Classrooms with a Mobile Application in Everyday Context
}

\author{
Leila Khubyari \\ Department of Foreign Languages, Kerman Branch, Islamic Azad University, Kerman, Iran \\ E-mail: leila_khubyari@yahoo.com \\ Mehry Haddad Narafshan (Corresponding author) \\ Department of Foreign Languages, Kerman Branch, Islamic Azad University, Kerman, Iran \\ E-mail: mnarafshan@yahoo.com
}

Received: December 21, 2015 Accepted: January 31, 2016 Published: February 1, 2016

doi:10.5296/ijele.v4i1.8961 URL: http://dx.doi.org/10.5296/ijele.v4i1.8961

\begin{abstract}
Technology especially, using mobile considered a booming future trend, facilitates education anywhere and anytime, and increases rapport among the growing number of second language learners. Consequently, this study probes the impact of Mobile Assisted Language Learning (MALL) on rapport in EFL classrooms. The population of this study was intermediate female EFL students (15-20 years old) at English Language institutes located in Kerman, district 2. A Cambridge Placement Test (CPT) was used to have almost homogenous groups. After administrating the CPT, 40 students who were randomly and equally assigned to the experimental and control groups (20 students in each group) were selected as the sample of this study. To see the impact of MALL on EFL learners' classroom rapport, the researcher utilized quantitative research method. The instrument applied in this study was a classroom rapport questionnaire. The result revealed that regular and immediate text messages can act as an effective way of establishing rapport between the teacher and the students.
\end{abstract}

Keywords: MALL, Rapport, EFL classrooms 


\section{Introduction}

In the 21st century, the need for inserting the principles of lifelong learning in education and in broader development policies seems to be more urgent than ever before. Technology especially, using mobile considered a booming future trend, facilitates education anywhere and anytime, and increases interest among the growing number of second language learners.

Language is a mean for communication. Mahu (2012) stated, "The English language has been the common language of the world for decades. It is now impossible to find a country where learning English has not become a norm" (p.374). Reddy (2012) claimed English is a global language in today's world because it is the only language that is spoken by so many in the world. As an international language, it is an urgent need for EFL learners to learn English language.

In the new era of technology and instant communication and in the global village where everything is connected through wireless networks, establishing international relationships and communications seems crucial and inevitable. English, as a lingua franca, has emerged as a way of referring to communication in English between speakers with different first languages (Seidlhofer, 2005). Since roughly only one out of every four users of English in the world is a native speaker of the language, most international interactions take place among 'non-native' speakers of English. According to Mahu (2012), English is the most spoken language around the world; 1 out of 5 persons understands it and it is estimated that there are380 million native speakers, 300 million who utilize English as a second language, and an additional 100 million who use it as a foreign language(Crystal,2003).

Since the initial introduction of computers into the field of second/foreign language education, a large number of practitioners have concurred that this technology holds great potential for language learning. The enthusiasm over computer technology, as a model of instruction in language classes, stems from the view that computer is sometimes more facilitating than teachers or tutors. Computers are capable of performing multiple tasks. They can organize, select, and present multiple sensory components (Al-Seghayer, 2001). In research on technology, the question is no longer whether technology is superior to non-technology, rather the question is how technology can be used effectively (Hegelheimer \& Tower, 2004). One of the concerns often raised in the domain of technology is how to use the potential of a computer to enhance the language learning process and how to use different media types in teaching and learning. This concern has been narrowed to the investigation of the efficacy of presenting information using multiple modalities such as text, audio, still picture, and dynamic video in the field of second and foreign language teaching (Al-Seghayer, 2001).

Teaching does not comprise just the classrooms, board markers and worksheets. The triumph of the teacher depends mainly on how she/he handles the students as human beings. Rapport is similar to trust and mutual liking. Rapport is the relation characterized by harmony, conformity, accord, or affinity. Rapport has been avoided in favor of other variables, such as methods of teaching modes of testing, and techniques of assessing teaching effectiveness, which can be more readily conceptualized and manipulated. Nonetheless, it is worth considering the role of rapport for no other reason than its contributions to effective teaching 
(Buskist \& Saville, 2001). Faranda and Clarke (2004) explained that rapport in language learning refers to the ability to maintain harmonious relationships based on affinity for others. Benefits of building rapport between students and teacher are that people like other people who have attention to them (Diero, 1997). And Students like teachers who think highly of them. Rapport is the interpersonal side of teaching. According to Ramsden (2003), rapport involves knowing the students and their learning styles and using the relationship with them to teach at a more personal level.

Research has shown that teacher-student rapport contributes to teacher effectiveness and student learning (Brown, 2004). Building rapport with students is an important component to successful communication especially when the subject is learning a second language (Nguyen, 2007). Teaching is as much about the technical merits of the instructor as it is about relationships in the classroom; successful teachers have learned how to build rapport with their students while challenging them to learn new material (Swenson, 2010).

Given the trends of what today young people like, enjoy, and prefer regarding technologies, MALL (mobile assisted language learning) allows students to actively participate in their learning process, and also allows teachers to get closer to the students. If one asks how students spend time, what kind of technological toys they are prone to, the answer is mobile devices. Therefore, if the idea of the teacher is to get students engage, then MALL would make half of the job because they would have the course itself right in their hand everywhere, anytime. The other half would be the course's structure, activities and content (Castillo et al., 2013).In consequence, providing the means for students to access course resources in their smart phones is a way to facilitate learning and keep them interested (Castillo et al., 2013).

Today, more than ever, the role of educational technology in teaching is of great importance because technology in the field of education can be a powerful tool. As a result, this study tries to answer the following question:

What is the effect of MALL on rapport in EFL classes?

\section{Statement of the Problem}

One of the major problems for EFL students is lack of rapport. Teaching is not as easy as presenting information and assigning work; teaching, like any form of communication, is a two-way street. There needs to be some kind of understood relationship between the teacher and the students so that the exchange of language and information results in students actually learning. That is why it is important to build a relationship with students. Teaching is about relationships. Positive rapport means having good relationships, and as teachers, one of the important goals is to build a classroom atmosphere where students feel comfortable and willing to learn. When positive classroom rapport exists, students feel a sense of belonging and are prepared to work and share information together. Although the effects of rapport building and their impact on students learning are obvious, most of the teachers ignore it and do not try to build it. (Haynes \& Backell , 2011). Rapport has been avoided in favor of other variables, such as methods of teaching, modes of testing, and techniques of assessing 
teaching effectiveness, which can be more readily conceptualized and manipulated. Nonetheless, it is worth considering the role of rapport for no other reason than its contributions to effective teaching (Buskist \& Saville, 2001).

In this study, mobile technology is used to establish an atmosphere of rapport and trust in the classroom to make teachers closer to the students.

\section{Significance of the Study}

This study is in significance of integrating MALL to create rapport in EFL classrooms. Recent research has highlighted the establishment and the importance of the teacher-student relationship in educational practice (Freire, 2003; Shor, 1992; Purpel \& McLaurin, 2004 cited in Giles, 2008).Claridge and Lewis (2005) have stated that the relationship with the learner is fundamental to the success of teaching. A good relationship will increase the learning the students get, as well as making it much more enjoyable for the teacher. Designing the alliance with the learner is part of making this success. Paterson (2005) has expressed that rapport is that wonderful bond that allows teacher and students to work and learn well together. The powerful teacher creates this relationship early in the year and works to maintain it. When good rapport has been established, students and teachers enjoy one another and the class, and students feel more motivated to do well.

Worley et al., (2007) stated that instructor-student relationships are not only important for effective communication to take place, but are vital for student learning. Tsui (1996) also noted that "establishing a good relationship with students is extremely important in creating a conducive learning atmosphere in the classroom" (p. 164). Rapport has also had a big impact on teaching second languages where interpersonal relationships help break down the barriers to learning. Teaching is as much about the technical merits of the instructor as it is about relationships in the classroom; successful teachers have learned how to build rapport with their students while challenging them to learn new material (Swenson, 2010).

In this study, considering the trends of what today young people like, enjoy, and prefer regarding technologies, MALL allows teachers to get closer to the students.

\section{Theoretical Framework of the Study}

There are two theoretical frameworks that build the foundation for utilizing mobile technology with language learners, namely McMillan's and Chavis' (1986) Sense of Community Theory, and Rovai's (2009) Online Sense of Community Theory. Each provides a segment of understanding for language learners and mobile technology. Explaining each theory and how it connects to mobile technology and language learning provides a greater understanding of the benefits of mobile technology with language learners.

\subsection{Sense of Community Theory}

Sense of Community was originally conceptualized by McMillan and Chavis (1986) and was 
developed to empirically-based research by Chavis (1986). McMillan and Chavis (1986) defined community as "a feeling that members have of belonging, a feeling that members matter to one another and to the group, and a shared faith that members' needs will be met through their commitment to be together" (p. 9). They also determined the vitality of community to a person's very being. "all need connections to others so that they have a setting and an audience to express unique aspects of their personality" (McMillan, 1996, p.1). According to McMillan and Chavis (1986), Sense of Community is a basic need of every person and does not exclude the classroom or a learning environment. There is also a spirit of belonging together, an authority that can be trusted, an awareness that trade and benefits come from being together, and sharing experiences becomes an art (McMillan, 1996).

\subsection{Online Sense of Community (Rovai, 2009)}

Sense of Community is a necessary component not only of humanity (McMillan \& Chavis, 1986), but also of the world of education in the virtual sense (Rovai, 2009). Rovai (2009) has applied this theory with his Classroom Community Likert scale measurement tool that has been implemented into empirical research for various qualitative and quantitative studies with virtual learners. Rovai's findings (2009) suggest it makes a difference in a student's perception of involvement in the learning experience and can ultimately impact the learning achievement outcome and satisfaction of students taking a particular course online (Rovai, 2009). The need for a sense of community does not exempt any ethnicity, gender, or age group, and is also valid with English Language Learners in the classroom, and is desired in an online community. Rovai (2009) has also implemented his Classroom Community Likert Scale into Distance Education and the virtual learning classroom. Many researchers and theorists in the world of education are trying to create methodologies, criteria, and curriculum guidelines for fostering a sense of community in the virtual classroom, because a sense of community affects performance, satisfaction and retention in virtual programs. However, the question that arises after a literature review is whether traditional classrooms also need a virtual sense of community. Rather than solely researching how to create a sense of community into the virtual classrooms, how does bringing a virtual sense of community aid in performance, perceived sense of community, and retention in the traditional classroom, specifically for language learners?

\section{Review of Literature}

\subsection{Emergence of Mobile Assisted Language Learning (MALL)}

With the emergence of different methods there has always been a recurrent use of different forms of technology. For instance, the espousal of the Audio Lingual method brought about an enormous focus on language laboratories, which gradually became the fashion of the day (Salaberry, 2001). Influenced by behaviorism, the language laboratories were equipped by drill-based computer assisted instruction in the 1960s, which then was progressively replaced by a more intelligent approach namely, computer assisted language learning (CALL) in the 1990s. As technologies continue to be used more extensively in teaching and learning settings, 
so does their propensity to shrink in size. "Other technologies that hold capacity for language learning include PDA, multimedia cellular phones, MP3 players, DVD players and digital dictionaries" (Zhao 2005, p.447).

As with other forms of technology, mobile assisted language learning (MALL) is a branch of technology-enhanced learning which can be implemented in numerous forms including face-to face, distant or on-line modes. However, different scholars in the field have underscored that MALL should be implemented in the classroom, taking the presence of learners as a paramount factor into consideration. In addition to mobile phones, there are other mobile devices that can be utilized for language learning in many of the same ways that phones are used. Mobile-Assisted Language Learning (MALL) is defined as "formal or informal learning mediated via handheld devices which are potentially available for use anytime, anywhere (Kukulska-Hulme \& Shield, 2008). These devices can include phones, tablets, electronic dictionaries, MP3 players, and gaming devices (Kukulska-Hulme \& Shield, 2008). The devices also offer connectivity which helps in the areas of language acquisition and community (Xiao-Bin, 2013). Studies show that MALL devices foster self-study, which in turn increases the acquisition of the English language. Language learners who study individually outside the classroom expand such language skills and areas as listening, reading, vocabulary, and grammar (Kukulska-Hulme \& Shield, 2008).

The literature suggests that the initial debate in the use of mobile phones for language learning had to do with preference, availability and usability of mobile phones (Stockwell, 2008; Melor $\&$ Chen, 2012). Some arguments claiming that mobile phone technology is not the most desired form of technology for language learning versus a PC desktop computer concerned the small size of the screen, the cost of using the mobile phone for every assignment based on Internet usage and mobile Internet plans, as well as the fact that the PC could be used in a quieter environment (Stockwell, 2008). Some other reasons why language learners preferred the use of a mobile phone for language learning were that the material can be accessed and completed anytime and anywhere, as well as that it was faster to use the mobile device as a language learning tool, because there was no time delay in waiting for the computer to boot up for usage (Stockwell, 2008).

However, as time has progressed, more specific uses aside from the Internet are becoming evident with a mobile phone in association with language learning enhancement. Now SMS texting and video recording are utilized in addition to social networking opportunities that can all be engaged through a mobile device. According to a Pew Institute Research Study (2012), " $92 \%$ of teen smartphone owners have gone online in the past 30 days on a cell phone(pewinternet.org). Tablets are another growing area of MALL devices that can enhance English language learning (Xiao-Bin, 2013). Studies show that language learners typically favor tablet devices in the English language acquisition process (Xiao-Bin, 2013). Tablets can provide many applications for learning English. However, while mobile phone ownership is mostly universal, the percentages of students that own tablets is much smaller. In one particular study testing the usage of tablets to learn English, only one student in a classroom owned a tablet, while every student had a mobile phone (Xiao-Bin, 2013). 


\subsection{Rapport Research in Organizational Contexts}

Recent research on instructor-student rapport grew out of past examinations of rapport building in various organizational contexts such as corporate negotiation (Nadler, 2007) and retail employee-customer relationships (Gremler \& Gwinner, 2008). This research demonstrates a variety of behaviors that contribute to building rapport between individuals. Research focusing on corporate negotiation (Nadler, 2007) suggested that rapport is built through nonverbal behaviors such as facing the other person, leaning forward, making eye contact, and mimicry of the other person through posture, facial expressions, tone of voice, and mannerisms. Nadler's (2007) research also reaches beyond the scope of nonverbal communication, and asserts that one can build rapport by conducting face-to-face meetings, chatting informally before conducting business, and through self-disclosure.

Gremler and Gwinner (2008), in a study on rapport building tactics used by retail employees with customers, found five significant themes of rapport building behaviors. These behaviors included uncommonly attentive behavior, common grounding behavior, courteous behavior, connecting behavior, and information sharing behavior. Uncommonly attentive behaviors refer to behaviors that were viewed as above-and-beyond by the customer. Common grounding behaviors refer to attempts by the employee to show what he/she has in common with the customer. Courteous behavior is exemplified through considerate behaviors that appear to have the best interests of the customer in mind. Connecting behavior is explained as an employees' attempt to form a bond with the customer. Last, information-sharing behaviors refer to an employee sharing information with the customer that is perceived to make the customers' experience better.

\subsection{Effects of Building Rapport in the Classroom}

Rapport building between instructors and students is increasingly viewed as essential to a positive classroom experience. Faranda and Clark (2004) listed rapport as one of the top six attributes that students believe are present in good instructors, and early research on rapport building (McLaughlin \& Erickson, 1981) suggested that rapport is crucial characteristic of being an "ideal" instructor. Schrodt and Witt (2006) explained the potential benefits of rapport building, stating, "few can deny the fundamental importance of instructors establishing... rapport with students at the beginning of a new semester" (p. 3). Frisby and Myers (2008), drawing from research by Roach, Cornett-Devito, and Devito (2005) succinctly explained the potential benefits of rapport building in a classroom setting: intuitively, an instructor who maintains positive rapport with students would also achieve a sense of liking from them, increase students' state motivation, and enhance students' satisfaction, in part because student's feelings of liking for instructors often evolves into liking for the course and increased learning.

The effects of rapport building between instructors and students align with assumptions of the Affective Learning Model (ALM) (Rodriguez, Plax, \& Kearney, 1996). The ALM posits that favorable instructor behaviors are essential to building relationships between students and instructors, which can help create positive student affect toward both the instructor and the class, which in turn may improve cognitive learning. Affective learning refers to students' 
feelings about course content, about enrolling in another course with similar content, and about the course instructor (Frisby \& Martin, 2010). Cognitive learning refers to the process of a student gaining knowledge related to course material and developing intellectual skills (Bloom \& Krathwohl, 1956). The ALM has been utilized by Communication Studies scholars to examine how instructor behaviors such as immediacy (Rodriguez et al., 1996) and rapport building (Frisby \& Martin, 2010) can increase students' affective and cognitive learning. Although the benefits of classroom rapport have been demonstrated, an in-depth look at how exactly to build rapport in the classroom is missing from the research (Frisby \& Martin, 2010). Since the ALM demonstrates that instructor behaviors can enhance cognitive learning, an understanding of the specific ways that rapport can be built in the classroom is warranted. By analyzing student reports of behaviors that build rapport in the classroom, this study contributes to the literature on rapport building by providing specific behaviors that instructors can use to enhance the classroom environment, which in turn may lead to increases in student learning.

Research has shown that teacher-student rapport contributes to teacher effectiveness and student learning. One area of research deals with meta-programs and how matching teacher and student language and behavior in the classroom enhances student learning or a student's perception of learning. Meta-programs are personality preferences that unconsciously influence an individual's language and behavior (Brown, 2004). "The mismatch of meta-programs is similar to watching the interaction of two people who do not speak a common language. Body language may provide some insight into the discussion but both parties will have a hard time understanding each other without a common verbal language. The same holds true when a teacher communicates with a student. If the teacher and student do not have the same meta-programs then both at the conscious and unconscious level, they will not connect and learning may not occur. Brown conducted interviews and focus groups with business students (2004). The results showed that factors such as instructors' knowledge of the subject, sense of humor, ability to teach to the students' level and willingness to answer questions were important to achieving competence (Brown, 2004).

A similar line of research looked at rapport building in the day to day or moment to moment interaction between an instructor and a student. Building rapport with students is an important component to successful communication especially when the subject is learning a second language. Nguyen researched building student rapport in an ESOL (English for speakers of other languages) grammar class in which he studied competent teachers and their approach to building rapport in the classroom (2007). The teachers effectively switched among a variety of techniques depending on the verbal and nonverbal queues they were receiving from the students. The techniques included "lexical items, special grammatical structures, formulaic expressions, speech tempo and body language" (Nguyen, 2007). The study showed that instructors were building rapport throughout the lesson as they focused on building an interpersonal relationship with the students. Through the interpersonal interactions, the students were able to observe the instructors communicating in the new language and then respond back thus reaffirming their learning (Nguyen, 2007).

Building rapport is not easy nor will it occur automatically after some period of time. In order 
to get to the point where an instructor can read a person's verbal or non verbal queues and then act appropriately takes experience and a desire to build a relationship. Murphy and Valdez show that challenges of collaborative learning are overcome with the implementation of a resistance breaking process that is grounded in rapport building (2005). The article lays out three phases that start with the first few meetings in which a low level of rapport is established and gradually builds to a high level of rapport; eventually, students feel comfortable in the classroom and start to learn more unique traits and characteristics about their classmates and instructors (Murphy \& Valdez, 2005).

Rapport is also essential in distance learning classes where the instructor has limited to no face time with students and where most teaching occurs online. One of the critical components to successful distance learning programs is building strong and continually growing student-instructor rapport (Sull, 2009). Sull encouraged instructors to be creative in building rapport and to use all available on line means to include chat rooms and discussion boards to increase positive contact with students. In a study done by Jones, et al. students in blended learning courses versus pure web based courses had more frequent message exchanges with both other students and their instructors (2009). Additionally, in the blended learning environment where the course meets a few times in person and the remainder is taught over the web, there was a higher incidence of rapport elements in messages and the online dialog or collaboration started earlier (Jones, et al., 2009). In teaching effectiveness studies, good rapport and the ability to establish rapport with students is cited as an important factor in student learning. In one such study, 220 secondary school principals were asked what the leading causes were of teacher ineffectiveness. The top three causes were classroom management skills, lesson implementation skills, and rapport with students (Torff \& Sessions, 2005). Content knowledge deficiencies were ranked lower, indicating that a teacher's knowledge of the subject matter was less of a cause of teacher inefficiencies than the ability to build rapport. In support of this, Teven and McCroskey (1996) found significant evidence to support their hypothesis that students who perceive their instructors as more caring will report they have learned more in the course. Once again, the caring element is a by product of the interpersonal relationship between the teacher and the students.

Teachers looking to advance in the ranks may use rapport building to build solid student evaluations at the expense of a rigorous course (Delucchi, 2000). Delucchi found that student perceived learning actually decreased with every one percent increase in the amount that students like their instructor (2000). Whereas, in the same study, an increase in likeability of the instructor resulted in an overall increase in the students perception of their instructor's teaching ability (Delucchi, 2000). Kozub found that rapport is positively correlated to overall student ratings of teacher effectiveness (2010). Lowman indicates that student ratings reflect the quality or level of rapport between students and their instructor (1995). Additionally, effective college teachers can create intellectual excitement while also build rapport with their students; success in one area alone will ensure effective teaching to at least some of the students (Lowman, 1995).

Although most of the rapport research is student centered, faculty has something to gain from a positive rapport with their students. Granitz et al., (2008) built a model for rapport which 
included three antecedents (approach, personality, and homophily) and four outcomes (student benefits, faculty benefits, benefits outside the classroom, and faculty-student benefits). There research was based on perceptions from business faculty in a variety of private and public schools. Their results indicated that increased rapport can have faculty benefits that include personal enjoyment and satisfaction in teaching, increased appreciation as a teacher, higher teaching evaluations, and an increased reputation within the school (Granitz et al., 2008). On the flip side, rapport has been shown to have a statistically significant positive effect on a student's attitude toward the teacher and toward the course material when the instructor established rapport with the student (Benson \& Cohen, 2005).

\section{Methodology}

The population of this study was intermediate female EFL students (15-20 years old) at English Language institutes located in Kerman, district 2. A Cambridge Placement Test (CPT) was used to have almost homogenous groups. After administrating the CPT, 40 students who were randomly and equally assigned to the experimental and control groups (20 students in each group) were selected as the sample of this study. To see the impact of MALL on EFL learners' classroom rapport, the researcher utilized quantitative research method. The instrument applied in this study was a classroom rapport questionnaire designed with some modifications (cultural and simplified) based on the questionnaires of Beishuizen et al., 2001; Wubbles, 200 6; Wubbels and Levy ,2006; Doll et al., 2007; and Arnon and Reichel, 2007. It consisted of twenty closed - ended questions. The five - point - scale was used for all responses with related labels (never, sometimes, often, usually, and always) to gather the data. The internal reliability of the questionnaire used in this study was 0.95 (pre-test) and 0.98 (post-test). It was obtained through Cronbach's Alpha formula. To ensure the validity of the questionnaire, a sample of ten university professors as experts of teaching English field were asked to leave their comments on the redundant items to mark unclear parts in the questionnaire. Then, the answers were analyzed based on the Content Validity Ratio Formula (CVR). According to Lawsche (1975), questions whose CVR was more than 0.81were chosen as the main items.

\section{Procedure}

As the first step, the students in both groups (control \& experimental) answered the classroom rapport questionnaire. The researcher checked to see whether all learners in experimental group had mobile phones or not. Some of them did not have mobile phones; therefore the researcher provided them with some sim-cards and made sure that there was at least one mobile phone in their families. Those learners who did not have mobile phones were asked to insert the provided sim-cards in a mobile phone provided by the researcher to do the activities according to the time table of sending SMS. Both groups received the same materials during the course considering the same teacher, and the same setting. Both groups participated in the study for 20 sessions. In both groups, the class content was practiced in the same way, but in experimental group, the students were sent text messages on different 


\section{Macrothink}

occasions that they had to answer within a planned time schedule. After sending messages for 20 sessions, both the experimental and the control groups were asked to answer the classroom rapport questionnaire to see the potential changes.

\section{Results}

Table 1. Class room Rapport in Control and Experimental Group (pre-test)

\begin{tabular}{|c|c|c|c|c|c|c|}
\hline & Classroo & n Rappc & & T-Test & df & P-Value \\
\hline Group & $\begin{array}{l}\text { Total } \\
\text { number }\end{array}$ & Mean & Std.Deviation & \multirow{3}{*}{0.31} & \multirow{3}{*}{38} & \multirow{3}{*}{0.8} \\
\hline Control & 20 & 35.20 & 9.51 & & & \\
\hline Experimental & 20 & 34.25 & 9.87 & & & \\
\hline
\end{tabular}

Table 2. Classroom Rapport in Control and Experimental Group (post-test)

\begin{tabular}{|l|l|l|l|l|l|l|}
\hline & \multicolumn{3}{|c|}{ Classroom Rapport } & T-Test & df & P-Value \\
\hline Group & $\begin{array}{l}\text { Total } \\
\text { number }\end{array}$ & Mean & Std.Deviation & & & \\
\cline { 1 - 4 } Control & 20 & 40.40 & 9.34 & -8.61 & 38 & 0.00005 \\
\cline { 1 - 4 } Experimental & 20 & 71.40 & 13.13 & & \\
\hline
\end{tabular}

Table 3. Classroom Rapport in Control Group (pre test \& post test)

\begin{tabular}{|l|l|l|l|l|l|l|}
\hline Time & N & Mean & Std.Deviation & T-Test & df & P-Value \\
\hline pre-test & 20 & 35.20 & 9.51 & -13.64 & 19 & 0.0005 \\
\hline post-test & 20 & 40.40 & 9.34 & & & \\
\hline
\end{tabular}

Table 4. Classroom Rapport in Experimental Group (pre test \& post test)

\begin{tabular}{|l|l|l|l|l|l|l|}
\hline Time & N & Mean & Std.Deviation & T-Test & df & P-Value \\
\hline pre-test & 20 & 34.25 & 9.87 & -13.73 & 19 & 0.0005 \\
\hline post-test & 20 & 71.40 & 13.13 & & \\
\hline
\end{tabular}




\section{Macrothink \\ International Journal of English Language Education \\ ISSN 2325-0887 \\ 2016, Vol. 4, No. 1}

\section{Discussion and Conclusion}

This study has investigated the effect of MALL on rapport in EFL classes. According to the results (tables 8.1-8.4), based on the P-Value, independent sample t- test and paired sample t-test, it can be said that there is significantly a positive relationship between MALL and rapport in EFL classes. Both groups (experimental \& control) promoted in terms of classroom rapport, but the findings supported the superiority of MALL. Therefore, the research hypothesis, there is a relationship between MALL and rapport in EFL classes, is accepted. The current findings show that regular and immediate text messages can act as an effective way of establishing rapport between the teacher and the students. Therefore, it is worthwhile exploring the various ways of how to utilize and implement mobile technology to increase rapport inside and outside the classroom. MALL enables the learners to learn in a friendly non-classroom environment. In fact, they can learn every time and everywhere they are.

\section{References}

Abbasi, M., \& Hashemi, M. (2013). The impact/s of Using Mobile Phone on English Language Vocabulary Retention. International Research Journal of Applied and Basic Sciences, 4(3), 541-547.

Al-Seghayer, K. (2001). The effects of multimedia modes on L2 vocabulary acquisition: A comparative study. Language Learning \& Technology, 5(1), 202-232.

Benson, T., \& Cohen, A. (2005). Rapport: its relation to student attitudes and behaviors toward teachers and classes. Faculty Forum, 32(4), 237-239.

Bloom, B. S., \& Krathwohl, D. R. (1956). Taxonomy of Educational Objectives: The Classification of Educational Goals, by a Committee of College and University Examiners. New York: Longmans.

Brown, N. (2004). What makes a good educator? The relevance of meta-programmes. Assessment and Evaluation in Higher Education, 29(5), 515-533.

Burston, J. (2013). Mobile-Assisted Language Learning: A Selected Annotated Bibliography of Implementation Studies 1994-2012. Language Learning\& Tecnology, 17(3), 157-225.

Chavis, D. M. et al. (1986). Sense of community through Brunswick's lens: A first look. Journal of Community Psychology, 14(1), 24-40.

Chavis, D. M., Hogge, J. H., McMillan, D. W., \& Wandersman, A. (1986). Sense of community through Brunswick's lens: A first look. Journal of Community Psychology, 14(1), 24-40.

Chinnery, G. ( 2006) Emerging technologies; Going to the MALL: Mobile Assisted Language Learning. Language Learning \& Technology, 10(1), 9-16.

Crystal, D. (2003).The Cambridge Encyclopedia of Language. Cambridge University Press. 


\section{MInstitute Macrothink $_{\text {Int }}$}

International Journal of English Language Education

ISSN 2325-0887

Delucchi, M. (2000). Don't worry, be happy: instructor likeability, student perceptions of learning, and teacher ratings in upper level sociology courses. Teaching Sociology, 28, 220-231.

Delucchi, M., \& Pelowski, S. (2000). Liking or learning? The effect of instructor likeability and student perceptions of learning on overall rating of teaching ability. Radical Pedagogy, 2(2).

Deng, H., \& Yinjuan,Sh. (2011). Self-directed English vocabulary learning with a mobile application in everyday context. $10^{\text {th }}$ World Conference on Mobile and Contextual Learning.

Faranda, W. T., \& Clarke, I. (2004). Student Observation of Outstanding Teaching: Implications for Marketing Educators. Journal of Marketing Education, 26, 271-281.

Frisby, B. N., \& Martin, M. (2010). Instructor-Student and Student-Student Rapport in the Classroom. Communication Education, 59, 146-164.

Granitz, N., Koernig, S., \& Harich, K. (2008). Now it's personal: antecedents and outcomes of rapport between business faculty and their students. Journal of Marketing Education, 31(1), 52- 65.

Gremler, D. D. (2004). The Critical Incident Technique in Service Research. Journal of Service Research, 7, 65-89. http://dx.doi.org/10.1177/1094670504266138

Gremler, D. D., \& Gwinner, K. P. (2008), Rapport-building Behaviors Used by Retail Employees. Journal of Retailing, 84, 308-324.

Hegelheimer, V., \& Tower, D. (2004). Using CALL in the classroom: Analysing student interaction in an authentic classroom. Journal of System, 32, 185-205.

Hu, Z. (2011). Vocabulary Learning Assisted by Mobile Phones: Perceptions of Chinese Adult Learners. Journal of Cambridge Studies, 8(1), 139-154.

Jones, J., Warren, S., \& Robertson, M. (2009). Increasing student discourse to support rapport building in web and blended courses using a 3D online learning environment. Journal of Interactive Learning Research, 20(3), 269-294.

Kozub, R. (2010). Relationship of course, instructor, and student characteristics to dimensions of student ratings of teaching effectiveness in business schools. American Journal of Business Education, 3(1), 33-40.

Kukulska Hulme, A. (2013). Mobile assisted language learning. In C. Chapelle (Ed.), The Encyclopedia of Applied Linguistics (pp. 3701-3709).

Kukulska-Hulme, A., \& Shield, L. (2008). An overview of mobile assisted language learning: from content delivery to supported collaboration and interaction. ReCALL, 20, 271-289.

Lowman, J. (1995). Mastering the Techniques of Teaching (2nd ed.). San Francisco: JosseyBass.

McMillan, D. W. (1996). Sense of Community. Journal of Community Psychology, 24(4), 


\section{$315-325$.}

McMillan, D. W., \& Chavis, D. M. (1986). Sense of community: A definition and theory. Journal of Community Psychology, 14(1), 6-23.

McLaughlin, M. L., \& Erickson, K. V. (1981). A Multidimensional Scaling Analysis of the "Ideal Interpersonal Communication Instructor." Communication Education, 30, 393-398. http://dx.doi.org/10.1080/03634528109378494

Mosavi Miangah, T., \& Nezarat, A. (2012).Mobile-Assisted Language Learning. International Journal of Distributed and Parallel Systems (IJDPS), 3(1), 309-319.

Murphy, M., \&Valdez, C. (2005). Ravaging Resistance: a model for building rapport in a collaborative learning classroom [Electronic Version], Radical Pedagogy, 7.1.1 (retrieved from the internet 21 April 2010).

Nadler, J. (2007). Build Rapport--and a Better Deal. Negotiation, 3, 9-11.

Nguyen, H. T. (2007). Rapport Building in Language Instruction: A Microanalysis of the Multiple Resources in Teacher Talk. Language \& Education: An International Journal, 21, 284-303. http://dx.doi.org/10.2167/le658.0

Roach, K. D., Cornett-DeVito, M. M., \& DeVito, R. (2005). A Cross-cultural Comparison of Instructor Communication in American and French Classrooms. Communication Quarterly, 53, 87-107. http://dx.doi.org/10.1080/01463370500056127

Rodriguez, J. I., Plax, T. G., \& Kearney, P. (1996). Clarifying the Relationship between Teacher Nonverbal Immediacy and Student Cognitive Learning: Affective Learning as the Central Causal Mediator. Communication Education, 45, 293-305. http://dx.doi.org/10.1080/03634529609379059

Rovai, A. P. (2009) Building a sense of community at a distance. International Review of Research in Open and Distance Learning, 3(1), 1-16.

Salaberry, M. R. (2001). The use of technology for second language learning and teaching: A retrospective. Modern Language Journal, 85, 39-56.

Schrodt, P., \& Witt, P. (2006). Students' Attributions of Instructor Credibility as a Function of Students' Expectations of Instructional Technology Use and Nonwerbal Immediacy. Communication Education, 55, 1-20. http://dx.doi.org/10.1080/03634520500343335

Small, M. (2014). Theoretical Implications of Various Mobile APpplications Used in English Language Learning. Teaching English with Technology, 14(1), 35-46.

Stockwell, G. (2008). Investigating learner preparedness for and usage patterns of mobile learning. ReCALL, 20(3), 253-270.

Stockwell, G. (2010). Using Mobile Phones For Vocabulary Activities: Examining the Effect of the Platform. Language Learning \& Technology, 14(2), 95-110.

Stockwell, G., \& Hubbard, P. (2013). Some emerging principles for mobile-assisted language 


\section{Macrothink}

International Journal of English Language Education ISSN 2325-0887 2016, Vol. 4, No. 1

learning. Monterey, CA: The International Research Foundation for English Language Education. Retrieved April 17, 2014 from http://www.tirfonline.org/wpcontent/uploads /2013/11/TIRF_MALL_Papers_StockwellHubbard.pdf.1-15.

Sull, E. (2009). Student engagement, motivation, and rapport. Distance Learning, 6(3), 90-94.

Torff, B., \& Sessions, D. (2005). Principals' perceptions of the causes of teacher Ineffectiveness. Journal of Educational Psychology, 97(4), 530-537.

Zhao, Y. (2005). The future of research in technology and second language education. In Y. Zhao (Ed.), Research in technology and second language learning: Developments and directions (pp. 445-457). Greenwich, CT: Information Age Publishing, Inc.

\section{Copyright Disclaimer}

Copyright for this article is retained by the author(s), with first publication rights granted to the journal.

This is an open-access article distributed under the terms and conditions of the Creative Commons Attribution license (http://creativecommons.org/licenses/by/3.0/). 